\title{
Technical Review of Mine Dewatering System Case Study Underground Gold Mine PT Bumi Suksesindo
}

\author{
$1^{\text {st }}$ Tedy Agung Cahyadi ${ }^{1}, 2^{\text {nd }}$ Sevian Anggoro ${ }^{2}, 3^{\text {th }}$ Singgih Saptono $^{3}, 4^{\text {th }}$ Suyono $^{4}, 5^{\text {th }}$ Indah Setyowati $^{5}$, \\ $6^{\text {th }}$ Sri Sugarto ${ }^{6}$ \\ sev.angg@gmail.com ${ }^{1}$ \\ Department of Mining Engineering, Faculty of Mineral Technology, UPN Veteran Yogyakarta ${ }^{1}$ \\ Undergraduate Student of Mining Engineering, Faculty of Mineral Technology, UPN Veteran \\ Yogyakarta $^{2}$ \\ Mine Plan Engineer, Decline Department, PT. Bumi Suksesindo ${ }^{3}$
}

\begin{abstract}
Minerals which located below the surface of the groundwater require pumping activities to carry out the mining activities. The problem that has occurred so far is that the work front located lower than the portal causes the waters from groundwater seepage and underground mining equipment to be collected and pooled on the work front. This causes the work area to be flooded and causes the mining activities to be delayed up to 5 hours. The study of the mine drainage system is expected to evaluate the existing mine drainage system in the PT Bumi Suksesindo underground mine, including analysis of groundwater seepage, mine water discharge, sump volume, pump requirements and alternative pumping system networks. Based on several trial and error experiments, the groundwater inflow is $1,17 \times 10^{-5} \mathrm{~m}^{3} \mathrm{~s}^{-1}$ on average at each seepage's location point. The recommendation to resolve the mine dewatering problems are an addition of a booster pump on sump 2 and sump 1, the dimensions of the sump has to be increased, add an airflow control valve to ensure that the source of air pressure is 3 bar, and a replacement of pump impeller to MT 231 coded impellers.
\end{abstract}

Keyword: Minerals, Technical Review, Mine Dewatering

\section{Introduction}

Mining involves extracting minerals located beneath the surface of the earth. Mineral which located below the surface of the groundwater requires pumping activities to carry out mining activities. In Indonesia, the majority of gold mine sites are located in igneous rock with many firactures that can drain water. If the mine sites were surrounded by a layer of an aquifer, then that layer holds a large amount of water. The dewatering system is one of the most difficult problem in mining activity, so it is true that all the mines are going to face problems with water even only once during the mine's production. (Chakrabarti, 1998).

The mine can operate if the pump dries seepage water during mining activities. The need for better mine water management is very necessary considered to how often a flood occurs, related to the depth of mining and costs of working inside rock layers that contain groundwaters. The issue of mine dewatering must still be controlled even though the mine has stopped operating. (Wolkersdorfer, 2008). Therefore, pumping networks is the most important aspect that must be considered to increase efficiency and reduce pumping costs. (Bridgwood et al., 1983).

An accurate prediction about mine dewatering are needed for feasibility studies and study on environmental impacts. This is due to the uniqueness of each underground mine and its comprehensive characteristics, so the analysis is needed to predict the necessity for mine 
dewatering. Although various empirical equations and analytical solutions have been published, they neither cover the complexity of each mine nor follows the actual conditions during the mining activity (Fawcet et al, 1984).

Hydraulic conductivity is the ability of a rock to conduct the groundwater at a certain velocity. The hydraulic conductivity of a fractured rock has more complexity (degree of heterogeneity and anisotropy) than the hydraulic conductivity of a sedimentary rocks (Cahyadi et al, 2014). The hydrogeological conditions of hard rock (metamorphic and igneous) in mine sites are commonly characterized by a fractured condition under complex geological settings consisting of a fault zone and fracture networks. The hydraulic properties's parameter are hydraulic conductivity (K), in-situ stress, rock matrix properties, fractures and aperture, density, persistence, orientation, interconnectivity, filling material and roughness (Cahyadi et al, 2017). To observe whereas the groundwater flow is in balance or not, many equipments are needed to make the observations. The results of the observations can be used to determine the possibility of a hydraulic connection between water in the surface and water on the underground mine.

The problem that has occurred so far is that the work front located lower than the portal causes water sourced from water seepage and underground mining equipment to be collected and pooled on the work front. The study of the mine drainage system is expected to evaluate the existing drainage system in the underground mine of PT Bumi Suksesindo, including analysis of groundwater seepage, mine water discharge, sump volume, pump requirements, and alternative pumping system networks.

\section{Materials and Methods}

\subsection{Hidraulic Conductivity of Aquifer}

Hydraulic conductivity is a value that shows the ability of aquifer layers in storing groundwater and the velocity of groundwaters through an aquifer. There has never been a packer test and slug test in the research location, so the assumption to find out the value of hydraulic conductivity was carried out using a provision by Cherry et al. 1979. Based on geological maps, the rocks in the study area were diorites and volcanic breccias. These rocks are classified as igneous rocks, so it has a hydraulic conductivity value range from $10^{-4} \mathrm{~ms}^{-1}$ to $10^{-8} \mathrm{~ms}^{-1}$. Based on several trial and error experiment, the hidraulic conductivity value that verge to actual is $3,352 \times 10^{-8} \mathrm{~ms}^{-1}$.

\subsection{Groundwater Elevation}

Based on geological maps, rocks in the research field are diorites and volcanic breccias. Using analysis of geological cross-section maps, the presence of groundwater is assummed to be found in the diorite layer due to its high amount of fractures characteristic. The diorite layered on the map is depicted in pink as a fractional aquifer medium that stores and flows groundwater through fractures and rock solids. The groundwater level is located at the boundary between diorites and volcanic breccias which on the map are described as green. In a small part of the underground mine area, it does not pass through diorites so that there is no groundwater level at some area.

\subsection{Groundwater Inflow}

The research area is an underground mine that is located below the PT BSI open pit mine area. The presence of the nearest river is 50 msouth of the research area and downstream of the river away from the underground mining area. The aquifer system in the study area is influenced 
by rock fractures that are connected to each other because there are many fractures in the rocks around the underground mine with an average spaced spacing of $8,43 \mathrm{~cm}$ and fracture aperture of $0,173 \mathrm{~mm}$. Based on observations in the field, it can be concluded that the most dominant source of water entering underground mines comes from rock fracture and porosity. The water that flows into the underground mine comes from groundwater seepage that flows along the mine. The parameters to calculates the seepage water discharge are hydraulic conductivity, groundwater level, depth of the center of underground mine, and mine cross-section radius. Groundwaters inflow is obtained at an average of $1,17 \times 10^{-5} \mathrm{~m}^{3} \mathrm{~s}^{-1}$ at each seepage location point. The groundwater inflow at each seepage points are calculated using El Tani (2003) Equation.

$$
\begin{aligned}
& Q=2 \pi \times K a q \times(A+H) \times\left(\ln \left(\frac{h}{r}+\sqrt{\frac{h^{2}}{r^{2}}-1}\right)\right)^{-1} \\
& A=h\left(1-a^{2}\right) \times\left(\left(1+a^{2}\right)^{-1}\right) \\
& a=r^{-1}\left(h-\left(h^{2}-r^{2}\right)^{-\frac{1}{2}}\right) \\
& \text { Explanation : } \\
& \mathrm{Q} \quad=\text { Groundwater inflow }\left(\mathrm{m}^{3} \mathrm{~s}^{-1}\right) \\
& \mathrm{Kaq} \quad=\text { Hidraulic Conductivity }\left(\mathrm{m} \mathrm{s}^{-1}\right) \\
& \mathrm{h} \quad=\text { Depth of the tunnel center (m) } \\
& \mathrm{H} \quad=\text { Groundwater Elevation }(\mathrm{m}) \\
& \mathrm{r} \quad=\text { Radius of the tunnel (m) }
\end{aligned}
$$

\subsection{Waters from Underground Mine Heavy Equipment}

Mining equipment activities in the work front mining area produces water with a certain amount of discharge so the water that inundates the underground mine is seepage water and the water from mining equipments. Mining water discharge is measured from mine equipment specifications and company data. The underground mine equipment used is the Atlas Copco M2D type jumbo drill with water discharge from the mining equipment used can be seen in Table 3.2.

Table 1. Mine Equipment Discharge Flowrate.

\begin{tabular}{cccc}
\hline Activities & Flowrate $\left(\mathrm{m}^{3} \mathrm{~s}^{-1}\right)$ & Time (hour) & $\begin{array}{c}\text { Volume } \\
(24 \text { Hours })\end{array}$ \\
\hline Rockbolting & 0,0012 & 2,35 & $9,67 \mathrm{~m}^{3}$ \\
Scalling & 0,00114 & 1 & $4,03 \mathrm{~m}^{3}$ \\
Boring & 0,00118 & 4,05 & $17,2 \mathrm{~m}^{3}$ \\
\hline
\end{tabular}

\subsection{Pump and Pipeline}

The pumps that used in this tunnel are consist of three types, namely Graco Husky 2150, Flygt B2125 and Challenger WT0X3. The Graco Husky 2150 pump is an aluminum-based pump which use air pressurized source of 3 bars. This pump conduct water from the working front to the sump 4 with an actual discharge of $0.001 \mathrm{~m}^{3} / \mathrm{s}$ using a 2-inch $(\mathrm{ca} .5 \mathrm{~cm})$ diameter and $25 \mathrm{~m}$ long polyethylene pipe. This pump works on average for 7 hours per day. The pump 
is not able to operate optimally because the incoming air pressure is in unstable condition, causes the work front becames flooded. The B2125 Flygt pump operates on each sump and as a booster pump between sumps. This pump uses a polyethylene pipe with a diameter of 2 inches (ca. 5 $\mathrm{cm}$ ). The pump works 24 hours per day, so the sump does not experience overflow conditions. The actual pump's flowrate and total head loss that has to be overcomed are different for each sump.

Pumps with the Challenger WTX03 brand are pumps that operate on the underground mine's portal and conduct water from the portal to the ore processing plant. This pump uses a $55 \mathrm{~kW}$ power source with a maximum efficiency of $75 \%$. This pump works to conduct water from the pump on sump 1 using an HDPE pipe with a 4-inch $(\mathrm{ca} .10 \mathrm{~cm}$ ) diameter and operates for 24 hours per day. The pipeline network in the underground mine are installed to connect each sump and to transport water into the underground mine portal. Total Headloss in the piping network can be seen in Table 2.

Table 2. Pump's Total Headloss.

\begin{tabular}{cc}
\hline Location & Head loss $(\mathrm{m})$ \\
\hline Work Front & 7,98 \\
Sump 4 & 21,178 \\
Sump 3 & 23,283 \\
Sump 2 & 42,618 \\
Sump 1 & 39,43 \\
\hline
\end{tabular}

\section{Result and Discussion}

\subsection{Groundwater Inflow into Each Sumps.}

The flowrate of groundwater discharge theoritcally cannot be the same as the actual seepage waters discharge from the actual flowrate measurement, because there is no hydraulic conductivity value data in the research location. The research approach is based on trial and error experiments so that the groundwater inflow is closest to reality. The analytical groundwater inflow is still greater than the actual discharge generally, this is to prioritize the pessimistic principle in the mine drainage system if the seepage water discharge increases.

Tabel 3. Groundwater Flow Rate in Each Sump.

\begin{tabular}{lr}
\hline Location & Flow Rate $\left(\mathrm{m}^{3} \mathrm{~s}^{-1}\right)$ \\
\hline Work Front & $1,179 \times 10^{-5}$ \\
Sump 4 & $4,718 \times 10^{-5}$ \\
Sump 3 & $1,143 \times 10^{-4}$ \\
Sump 2 & $7,7,26 \times 10^{-5}$ \\
Sump 1 & $1,913 \times 10^{-5}$ \\
\hline
\end{tabular}

\subsection{Analysis Pump's Ability and Necessity}

The pump conduct water from the working front at an altitude of 38 meters above the mine portal at an altitude of 163 meters above sea level. The pumping mine water in underground mines uses two types of pumps, namely an air-powered pump ordered Graco Husky 2150 and a Submersible Pump Flygt B2125 to convey water from the working front to the portal. The pumps network in the study area uses 4 pumps that located on each sump. The pump network can overcome the amount of groundwater inflow and the total headloss except for the pump on sump 2 and sump 1. Therefore, it is necessary to add a booster pump to overcome the total 
headloss. Based on the calculation, it can be resolved by adding just one booster pump between sump 4 to sump 3 and sump 3 to sump 2.

Tabel 4. Effect of the Booster Pump.

\begin{tabular}{ccc}
\hline Location & Headloss Then $(\mathrm{m})$ & Headloss Now $(\mathrm{m})$ \\
\hline Sump 2 & 42,618 & 22,32 \\
Sump 1 & 39,43 & 20,22 \\
\hline
\end{tabular}

\subsection{Analysis on Sump Dimension}

In reality, the sumps are capable to gather the mine's water but after calculation, only Sump 4 is still able to accommodate incoming mine water. So from that, the sump dimension needs to be changed to be able to accommodate the mine water discharge. Based on the calculation of groundwater inflow, it was found that Sump 4 was the only one that still sufficient to accommodate the volume of seepage water, while in other sumps became overflow. Therefore, it is necessary to change the dimensions of the Sump 1 to Sump 3 to accommodate the groundwater inflow. Each sump has the same beamshape and dimensions, by $3 \mathrm{~m}$ long, $4.5 \mathrm{~m}$ wide, and $0.5 \mathrm{~m}$ deep.

Tabel 4. Effect of the Booster Pump.

\begin{tabular}{ccc}
\hline Location & $\begin{array}{c}\text { Pump Flow Rate } \\
\left(\mathrm{m}^{3} \mathrm{~s}^{-1}\right)\end{array}$ & $\begin{array}{c}\text { Water Volume } \\
\left(\mathrm{m}^{3}\right)\end{array}$ \\
\hline Front Work & 0,000437 & 6,719 \\
Sump 4 & 0,000405 & 5,865 \\
Sump 3 & 0,000468 & 9,783 \\
Sump 2 & 0,000483 & 8,886 \\
Sump 1 & 0,000475 & 7,415 \\
\hline
\end{tabular}

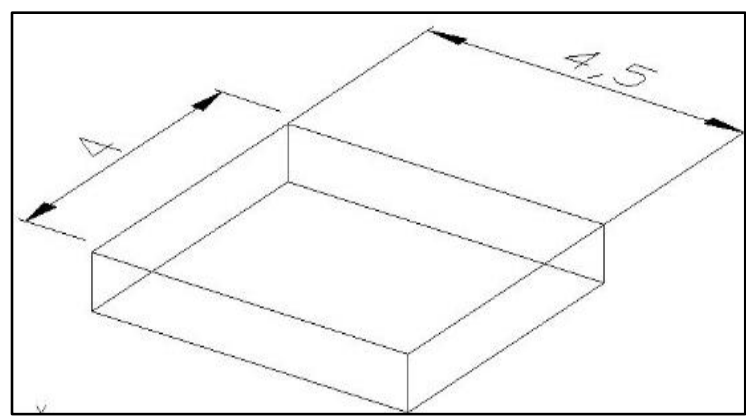

Fig. 3. Dimention of Sump Recommendation

\subsection{Pump Optimalization on Work Front Alternatives}

Alternative Increase in Pump Discharge. In the actual condition, the pump discharge at the working front is $0.001 \mathrm{~m}^{3} \mathrm{~s}^{-1}$ and it works for 7 hours per day. The groundwater seepage discharge flowrate is $0,000369 \mathrm{~m}^{3} \mathrm{~s}^{-1}$ and mining equipment water discharge flowrate is $0.00352 \mathrm{~m}^{3} \mathrm{~s}^{-1}$ for 24 hours per day so this is the answer of what makes the front work area are always flooded. The first alternative is to ensure that the number of pressurized-air intake is always at 3 bars so the pump discharge will increase to $0.00546 \mathrm{~m}^{3} \mathrm{~s}^{-1}$. The water on the working front which initially can be dried in 20.2 hours has becomes faster at 1.62 hours. Alternative Addition of Air Pressure. The second alternative is to increase pump discharge by increasing the source of pump power, that is the air pressure. With the condition still able to overcome the 
total head, the second alternative pump discharge flowrate is $0.00854 \mathrm{~m}^{3} \mathrm{~s}^{-1}$. Water on the working front that was originally on the first alternative can be dried in 1.62 hours to 1.03 hours in the second alternative. The graph of the actual pump discharge ratio and alternatives can be seen in Figure 1.

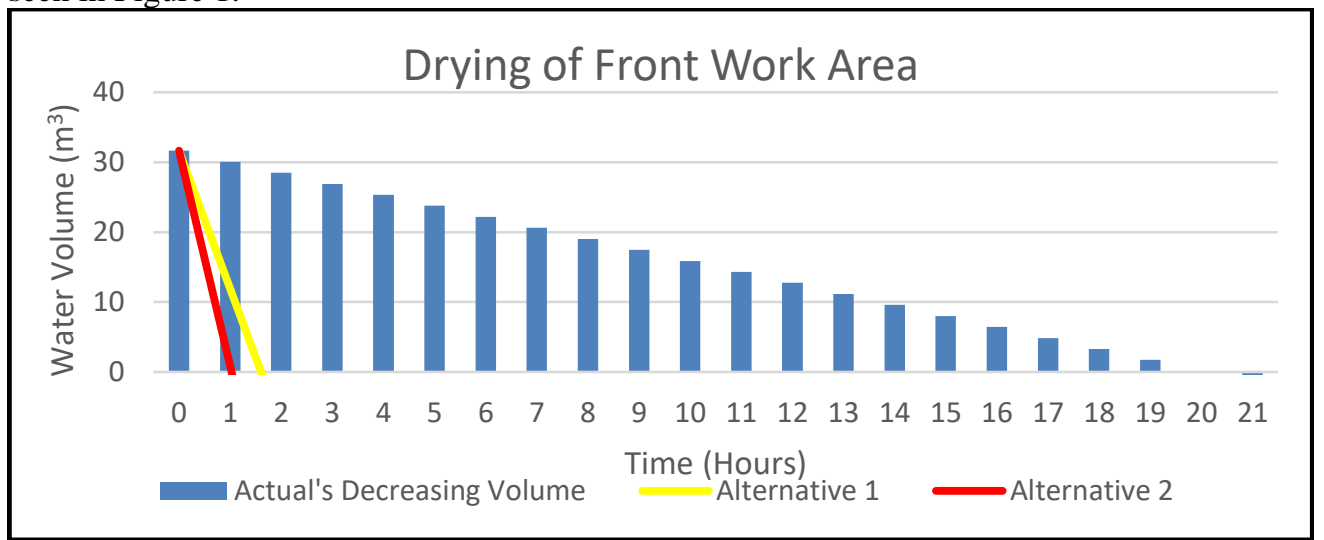

Fig. 3. Graph of Alternatives to Dries the Front Work Area

\subsection{Pump Optimalization on Each Sump Alternative.}

Alternative Addition of Booster Pumps. In the actual condition, the pump discharge in the sumps are capable to flow but the total pump headloss that has to be overcomed is $42.618 \mathrm{~m}$; and $39.43 \mathrm{~m}$ on Sump 2 and Sump 1. This causes the water in the sump maybe will goes overflow in next minig advance, so it is necessary to add a booster pump to reduce the pump's total head loss on the sump 2 and sump 1. This first alternative pump discharge has increased to become $0,000469 \mathrm{~m}^{3} \mathrm{~s}^{-1}$. Because of that, so the water in the Sump 2 and Sump 1 sump can be dried in 28.02 hours and 29.79 hours.

\subsubsection{Alternative Replacement of Pump Impeller with MT Code 231.}

In the first alternative of the pump network does can dry the sump, but the time that needed exceeds 24 hours, it is necessary to do an alternative in pump discharge by increase the flow rate but keep the pumps to be able to overcome the total head loss at each pump around by $23.283 \mathrm{~m}$. The pump discharge could be increased into amount of $0.007 \mathrm{~m} 3 \mathrm{~s}-1$.

\subsubsection{Alternative Replacement of Pump Impellers with 234 HT Codes.}

Impeller replacement at the pump aims to further increase the pump discharge while still being able to overcome the pump's total head. The original pump impeller had a MT 232 impeller code with a power source of 9.5 when it was converted into an impeller.

Tabel 5. Time to Dries the Sump.

\begin{tabular}{lllll}
\hline Location & $\begin{array}{l}\text { Alternative } \\
\text { (hours) }\end{array}$ & $\begin{array}{l}\text { Alternative } \\
\text { (hours) }\end{array}$ & $\begin{array}{l}\text { Alternative } \\
\text { (hours) }\end{array}$ \\
\hline Sump 4 & 28,02 & 1,62 & 0,945 \\
Sump 3 & 29,79 & 1,99 & 1,163 \\
Sump 2 & 28,38 & 1,9 & 1,108 \\
Sump 1 & 27,4 & 1,83 & 1,07 \\
\hline
\end{tabular}




\section{Conclution}

Groundwater inflow was calculated based on the El Tani formula (2003) with the approach of the value of hydraulic conductivity according to Cherry that obtained at $3.352 \times 10^{-8} \mathrm{~m} \mathrm{~s}^{-1}$, so that analytical groundwater inflow was found to be an average of $1.17 \times 10^{-5} \mathrm{~m}^{3} \mathrm{~s}^{-1}$ at each seepage point location, while the actual groundwater seepage discharge is an average of 8.564 $\mathrm{x} 10^{-6} \mathrm{~m}^{3} \mathrm{~s}^{-1}$. This analytical calculation is quiet close to actual groundwater seepage at the tunnel so the recommendation of designing the underground mine dewatering system is using this analytical groundwater seepage flowrate value.

Improvements recommendation of pumping networks in the underground mine dewatering system are follows:

1. The addition of a booster pump where located on $167 \mathrm{~m}$ far from the Sump 2 and $125 \mathrm{~m}$ far from the Sump 1 so that the pump is able to overcome the total head loss.

2. The change in the volume of the Sump 1, Sump 2, and Sump 3 becomes $10.8 \mathrm{~m}^{3}, 9 \mathrm{~m}^{3}$ and $8.1 \mathrm{~m}^{3}$ to be able to accommodate groundwater inflow discharge at each seepage location.

3. Alternatives recommendation to optimize the pump in each sumps is the replacement of MT 231 coded impellers so that the pump discharge increases to $0.007 \mathrm{~m}^{3} / \mathrm{s}$, and the drying time of the recess becomes 1.62 hours to 1.99 hours.

\section{Acknowledgement}

A huge grattitude to the Decline Department of PT Bumi Suksesindo for allowed me to did my research in Tujuh Bukit Underground Mine and Lembaga Penelitian dan Pengabdian Kepada Masyarakat (LPPM) UPN "Veteran" Yogyakarta for the financing support. Hopefully this research will be meritorious to others researches in the future.

\section{References}

[1] Bridgwood, 1983, "Selecion And Optimization Of Mine Pumping Systems", International Journal of Mine Water.

[2] Cahyadi T.A., Widodo L.E., 2017, Hidraulic Conductivity Modelling of Fractured Rock at Grasberg Surface Mine, Papua-Indonesia .

[3] Cahyadi T.A., Notosiswoyo S., 2014, "Distribusi Sebaran Konduktivitas Hidraulik Dari Hasil Uji Akuifer - Constant Head Permeabilitas Pada Batuan Sedimen Secara Heterogen”, Prosiding TPT XXIII Perhapi 2014.

[4] Cekic, Ljuban, 1991, "Dewatering System for Underground and Surface Mine in the Kreka Coal Basins", Tuzla : Mining Institute.

[5] Chakrabarti P. K., 1998, "Mine Pumps for Underground Drainage", (CMPDI), Ranchi: Central Mine Planning \& Design Institute Limited.

[6] Chow V., 1959, “Open Channel Hydraulic, Technology, and Engineer”, West Caldwell: The Blackburn Press.

[7] Kumar N., Shubayan Sarkar, 2013, "Review on Dewatering Pumping Network for Underground Coal Mine", International and 16th National Conference on Machines and Mechanisms.

[8] Patrick J, P., "Construction Dewatering (New Methode and Applications)", 3rd Edition, John Wiley \& Sons, New York, P 185-193 and 247-253.

[9] Rasul, M. G. dan Vermeulen P.J., 2007, "Improvement Strategies for Mine Dewatering Process", Queensland : Central Queensland University

[10] Wolkersdorfer, Christopher, 2008, "Water Management At Abandoned Flooded Underground Mines", Berlin : Springer Berlin Heidelberg. 